\title{
Aktivitas aglutinin dari beberapa jenis rumput laut di Teluk Manado
}

\section{Jenny Kumajas*}

Ilmu Kimia FMIPA, Universitas Negeri Manado, Tondano, 95619, Indonesia

INFO ARTIKEL

Diterima 1 Juni 2017

Disetujui 5 Juli 2017

\section{Key word:}

Agglutinin,

Seaweed,

Manado Bay

\section{Kata kunci:}

Agglutinin,

Rumput laut,

Teluk Manado

*e-mail:

jennykumajas@unima.ac.id.com

*Telp:

081244501244

\section{A B S T R A C T}

\begin{abstract}
Manado Bay waters have a high diversity of seaweed. This study aims to find the seaweed in Manado Bay waters that have aglutinin activity. Seaweed samples were taken in Manado Bay. After cleaned and identified, the samples were extracted. The extract was tested on human red blood cells (erythrocytes) of 4 types ( $A, B, O$ and $A B)$ with controls made without addition of extracts. The activity of agglutinin is determined by the agglutination titer of the highest dilution which causes cell agglutination. Agglutinin activity of each type of seaweed was tested at various temperature and $p H$. Among five species of seaweed that were tested, only three were agglutinated human red blood cells types $A, B, O$ and $A B$. Halimeda macroloba and $H$. taenicola did not show any aglutinin activity. Based on the research, it can be concluded that Ulva fasciata seaweed, Halymenia durvillaei and Laurencia obtusa from Manado Bay waters have agglutinin activity.
\end{abstract}

\begin{abstract}
A B STRAK
Perairan Teluk Manado memiliki keragaman rumput laut yang tinggi. Penelitian ini bertujuan untuk mencari jenis-jenis rumput laut dari perairan Teluk Manado yang memiliki aktivitas aglutinin. Sampel rumput laut diambil di sekitar Teluk Manado. Setelah dibersihkan dan diidentifikasi jenisnya, sampel dihaluskan dan diekstraksi. Ekstrak diuji pada sel darah merah (eritrosit) manusia dari 4 golongan $(\mathrm{A}, \mathrm{B}, \mathrm{O}$ dan $\mathrm{AB}$ ) dengan kontrol dibuat tanpa penambahan ekstrak. Aktivitas agglutinin ditentukan berdasarkan titer aglutinasi pada cekungan dengan pengenceran tertinggi yang masih menyebabkan aglutinasi sel. Aktivitas agglutinin tiap jenis rumput laut diuji pada berbagai temperatur dan $\mathrm{pH}$. Dari lima jenis rumput laut yang diuji, hanya tiga yang mampu mengaglutinasi sel darah merah manusia golongan A, B, O dan AB. Halimeda makroloba dan H. taenicola tidak menunjukkan adanya aktivitas aglutinin. Berdasarkan hasil penelitian, dapat disimpulkan bahwa rumput laut jenis Ulva fasciata, Halymenia durvillaei dan Laurencia obtusa dari perairan teluk Manado memiliki aktivitas agglutinin.
\end{abstract}

\section{Pendahuluan}

Aglutinin atau lektin adalah substans bioaktif yang mempunyai distribusi luas di alam dan dikenal sebagai protein atau glikoprotein yang dapat mengikat sakarida atau gula secara spesifik. Substans ini dapat digunakan untuk menentukan struktur gula pada permukaan sel [1], terapi tumor [2,3], alat kontrasepsi [4], pertahanan terhadap mikroorganisme [5], anti-nociceptif dan antiinflamasi [6].

Beberapa peneliti melaporkan bahwa rumput laut merupakan salah satu sumber aglutinin atau lektin [1,2,6-16]. Pencarian sumber-sumber aglutinin yang baru dari alam kini banyak tertuju pada biota laut, terutama di daerah tropis yang memiliki keragaman jenis yang tinggi.

Pencarian sumber-sumber aglutinin yang baru dari alam kini banyak tertuju pada biota laut, terutama di daerah tropis yang memiliki keragaman jenis yang tinggi. Salah satu sumber aglutinin yang potensial adalah rumput laut. Perairan Teluk Manado 
memiliki keragaman rumput laut yang tinggi. Karena itu, perlu dilakukan penelitian untuk mendapatkan jenis-jenis rumput laut yang memiliki kandungan aglutinin dari daerah ini.

Penelitian ini bertujuan untuk mencari jenis-jenis rumput laut dari perairan Teluk Manado yang memiliki aktivitas aglutinin. Di samping itu, akan ditentukan aglutinin yang spesifik terhadap golongan darah manusia.

\section{Bahan dan Metode}

Sampel rumput laut diambil di sekitar Teluk Manado, kemudian dicuci dengan air laut untuk mengeluarkan lumpur, pasir dan organisme menempel. Setelah diidentifikasi jenisnya menurut Atmajaya [17], sampel dihaluskan dan diekstraksi di Laboratorium Kimia Fakultas Matematika dan Ilmu Pengetahuan Alam Universitas Negeri Manado di Tondano.

Ekstraksi dilakukan berdasarkan metode ekstraksi protein [18] yang umum dilakukan dengan beberapa modifikasi. Rumput laut halus ditambahkan fosfat buffer dan disaring menggunakan saringan kasar. Filtratnya disentrifus dengan kecepatan 15.000 rpm selama 3 menit. Supernatannya ditambahkan garam ammonium sulfat secara bertahap sambil diaduk, kemudian disentrifus pada kecepatan $3.500 \mathrm{rpm}$ selama 15 menit untuk mengendapkan proteinnya. Endapan protein didialisis pada membrane selulosa selama 12 jam pada temperature rendah. Hasilnya diuji pada sel darah merah (eritrosit) manusia dari 4 golongan (A, $\mathrm{B}, \mathrm{O}$ dan $\mathrm{AB}$ ).

Suatu seri pengenceran $2 x$ dari $100 \mu \mathrm{L}$ larutan ekstrak protein makroalga dibuat pada mikrotiter plate. Kontrol dibuat tanpa penambahan ekstrak. Dengan volume yang sama, suspense eritrosit (1\%) ditambahkan pada tiap cekungan baik yang mengandung ekstrak maupun control. Setelah inkubasi selama 2 jam pada temperature kamar, dilakukan penentuan jenis-jenis rumput laut yang memiliki aktivitas agglutinin terhadap eritrosit manusia. Aktivitas agglutinin ditentukan berdasarkan titer aglutinasi pada cekungan dengan pengenceran tertinggi yang masih menyebabkan aglutinasi sel.

Untuk menguji pengaruh pemanasan terhadap aktivitas aglutinin, tiap $1 \mathrm{~mL}$ larutan ekstrak dipanaskan selama 1 jam pada temperatur $30,40,50,60,70,80,90{ }^{\circ} \mathrm{C}$. Setelah didinginkan kembali pada temperatur $4^{\circ} \mathrm{C}$ dan disentrifus, diuji pada sel darah merah manusia. Pengaruh $\mathrm{pH}$ terhadap aktivitas aglutinin dilakukan dengan melarutkan tiap jenis ekstrak dalam buffer 3, 4, 5, 6, 7, 8, 9 dan 10. Setelah inkubasi 1 jam pada temperatur $4^{\circ} \mathrm{C}$ dan disentrifus, diuji aktivitasnya terhadap sel darah merah manusia.

\section{Hasil dan Pembahasan}

Telah berhasil dikumpulkan lima jenis rumput laut dari perairan pantai Teluk Manado. Ekstrak kelima jenis rumput laut diuji pada sel darah merah manusia dari 4 golongan darah $\mathrm{A}, \mathrm{B}, \mathrm{O}$, dan $\mathrm{AB}$. Aktivitas aglutinin kelima jenis rumput laut ditunjukkan pada tabel 1.

Tabel 1. Aktivitas aglutinin beberapa jenis rumput laut terhadap sel darah merah manusia

\begin{tabular}{lllll}
\hline \multirow{2}{*}{ Rumput Laut } & \multicolumn{5}{c}{ Titer aglutinasi* } \\
\cline { 2 - 5 } & A & B & O & AB \\
\hline Halymenia durvillaei & 4 & 3 & 3 & 4 \\
Laurencia obtusa & 3 & 4 & 3 & 3 \\
Ulva fasciata & 4 & 5 & 5 & 4 \\
Halimeda macrolaba & - & - & - & - \\
Halimeda taenicola & - & - & - & - \\
\hline
\end{tabular}

*: nilai seri pengenceran $2 x$ yang masih menyebabkan aglutinasi positif

Tabel 1 menunjukkan bahwa hanya tiga jenis rumput laut yang mampu mengaglutinasi sel darah merah manusia golongan A, B, O dan AB. Halimeda makroloba dan $H$. taenicola tidak menunjukkan adanya aktivitas aglutinin. Sesuai dengan kemampuan mengaglutinasi sel darah merah manusia, maka aglutinin dari ketiga jenis rumput laut tersebut dikategorikan sebagai aglutinin yang tidak spesifik karena dapat mengaglutinasi keempat golongan darah manusia. Beberapa peneliti di Jepang juga menemukan beberapa jenis rumput laut yang tidak spesifik terhadap golongan darah manusia $[18,19]$.

Kemampuan mengaglutinasi keempat golongan darah manusia tidak banyak berbeda. Secara umum, aktivitas aglutinin 
Ulva fasciata cenderung lebih tinggi dibandingkan dengan Halymenia durvillaei dan Laurencia obtusa. Perbedaan aktivitas aglutinin dapat disebabkan oleh perbedaan kandungan jumlah molekul aglutinin dari ekstrak atau jumlah jenis molekul aglutinin.

Pengaruh pemanasan dan $\mathrm{pH}$ terhadap aktivitas aglutinin diuji pada ekstrak Halymenia durvillaei, Laurencia obtusa dan Ulva fasciata.

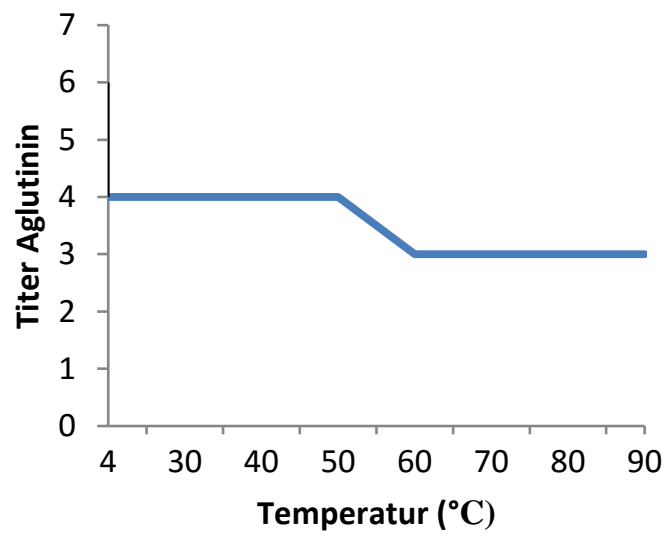

(A)

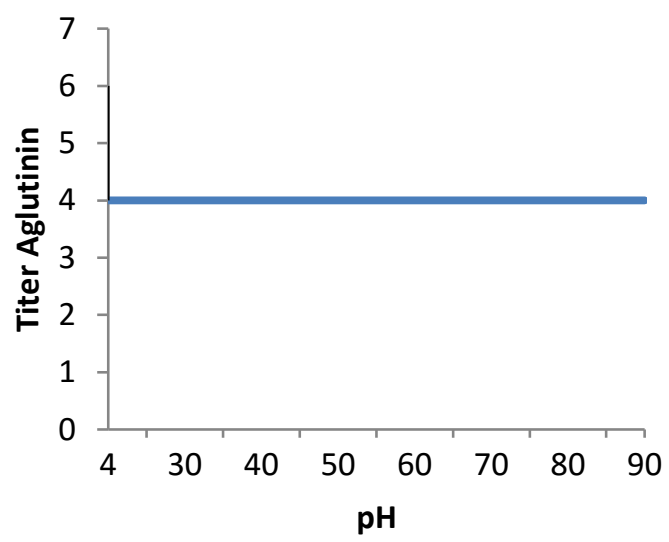

(B)

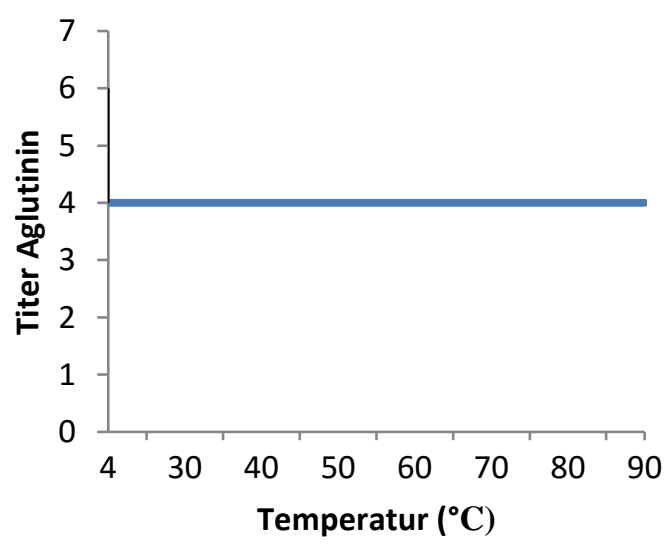

(C).

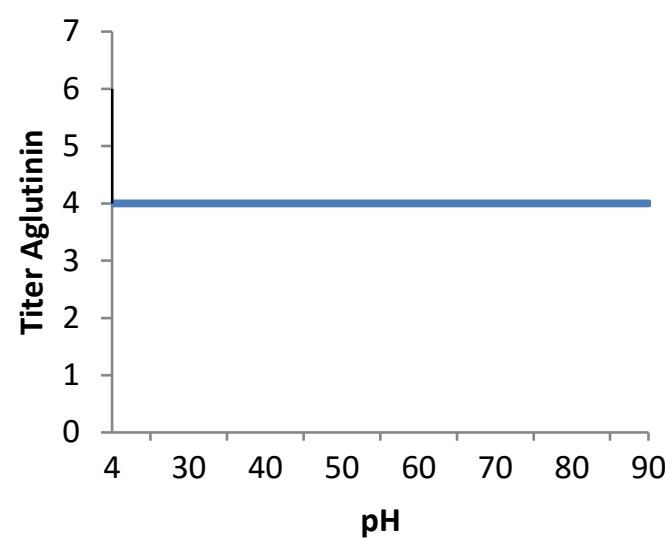

(D)

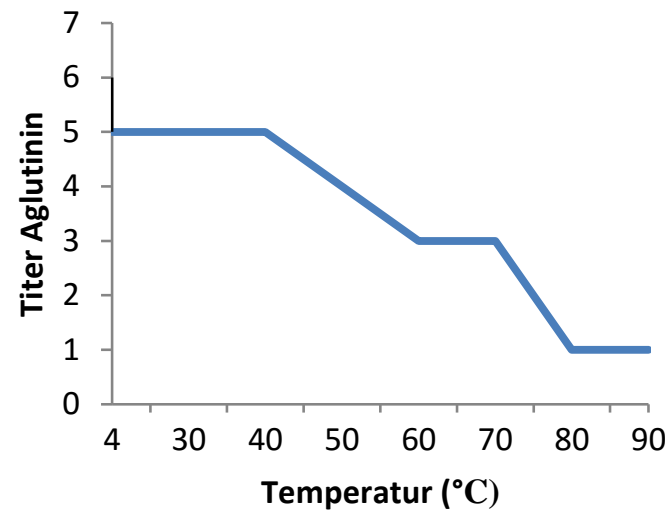

(E)

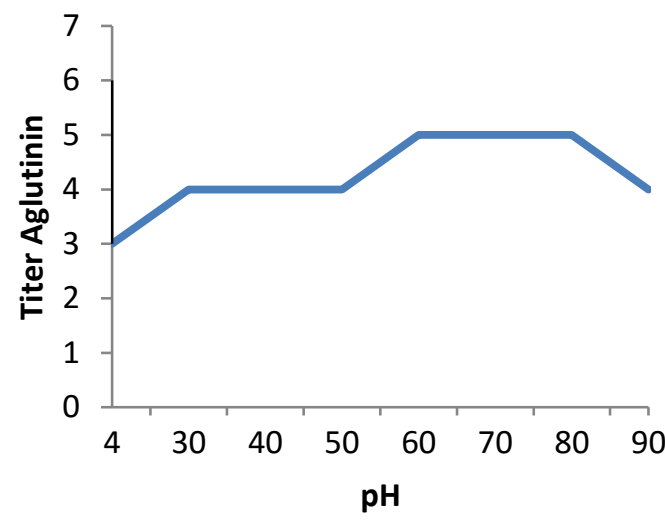

(F)

Gambar 1. (A) Pengaruh pemanasan terhadap aktivitas aglutinin Halymenia durvillaei ; (B) Pengaruh $\mathrm{pH}$ terhadap aktivitas aglutinin Halymenia durvillaei; (C) Pengaruh pemanasan terhadap aktivitas aglutinin Laurencia obtusa; (D) Pengaruh $\mathrm{pH}$ terhadap aktivitas aglutinin Laurencia obtusa; $\{\mathrm{E}$ ) Pengaruh pemanasan terhadap aktivitas aglutinin Ulva fasciata; (F) Pengaruh $\mathrm{pH}$ terhadap aktivitas aglutinin Ulva fasciata 
Gambar 1 menunjukkan bahwa temperatur dan $\mathrm{pH}$ berpengaruh terhadap aktivitas aglutinin Ulva fasciata. Aktivitas aglutinin Halymenia durvillaei hanya menurun sedikit pada $\mathrm{pH} 60^{\circ} \mathrm{C}$ namun tidak terpengaruh oleh perubahan $\mathrm{pH}$ sampai $\mathrm{pH}$ ekstrim. Aktivitas aglutinin Laurencia obtusa tidak terpengaruh oleh perubahan temperatur dan $\mathrm{pH}$ sampai temperatur dan $\mathrm{pH}$ ekstrim.

Kecuali pada Laurencia obtusa, aktivitas aglutinin menurun mulai temperatur $40^{\circ} \mathrm{C}$, namun relatif stabil terhadap perubahan $\mathrm{pH}$. Hasil penelitian ini menunjukkan bahwa secara umum temperatur lebih berpengaruh dibandingkan $\mathrm{pH}$. Hal yang sama ditemukan oleh Hori [18], Takahashi dan Katagiri [19] pada Agardhiella tenera, Gracilaria verrucosa, G. Bursa-pastoris, Ulva lactuca, Enteromorpha linza dan Bodlea coacta yang aktivitas aglutininnya menurun pada temperatur $50^{\circ} \mathrm{C}$, namun relatif stabil pada kisaran $\mathrm{pH} 3$ - 9.

\section{Kesimpulan}

Berdasarkan hasil penelitian, dapat disimpulkan bahwa rumput laut jenis Ulva fasciata, Halymenia durvillaei dan Laurencia obtusa dari perairan teluk Manado memiliki aktivitas agglutinin. Aktivitas agglutinin Laurencia obtusa tidak dipengaruhi temperature dan $\mathrm{pH}$ sedangkan Ulva fasciata sebaliknya, sementara Halymenia durvillaei labil pada temperature tinggi namun stabil terhadap $\mathrm{pH}$.

\section{Daftar Pustaka}

1. Ambrosio, A. L.; Sanz, L.; Sánchez, E. I.; Wolfenstein-Todel, C.; Calvete, J. J. Isolation of two novel mannan-and Lfucose-binding lectins from the green alga Enteromorpha prolifera: biochemical characterization of EPL-2. Arch. Biochem. Biophys. 2003, 415, 245250.

2. Pinto, V.; Debray, H.; Dus, D.; Teixeira, E. H.; De Oliveira, T. M.; Carneiro, V. A.; Teixeira, A. H.; Nagano, C. S.; Nascimento, K. S.; Sampaio, A. H.; others Lectins from the red marine algal species Bryothamnion seaforthii and
Bryothamnion triquetrum as tools to differentiate human colon carcinoma cells. Adv. Pharmacol. Sci. 2009, 2009.

3. Blonski, K.; Milde-Langosch, K.; Bamberger, A.-M.; Osterholz, T.; Utler, C.; Berger, J.; Loening, T.; Schumacher, U. Ulex europeus agglutinin-I binding as a potential prognostic marker in ovarian cancer. Anticancer Res. 2007, 27, 27852790.

4. Snyder, M. G.; Zaneveld, L. J. Treatment of cervical mucus with lectins: effect on sperm migration. Fertil. Steril. 1985, 44, 633-637.

5. Teixeira, E. H.; Napimoga, M. H.; Carneiro, V. A.; De Oliveira, T. M.; Nascimento, K. S.; Nagano, C. S.; Souza, J. B.; Havt, A.; Pinto, V. P. T.; Gonçalves, R. B.; others In vitro inhibition of oral streptococci binding to the acquired pellicle by algal lectins. J. Appl. Microbiol. 2007, 103, 1001-1006.

6. Silva, L. M. C. M.; Lima, V.; Holanda, M. L.; Pinheiro, P. G.; Rodrigues, J. A. G.; Lima, M. E. P.; Benevides, N. M. B. Antinociceptive and anti-inflammatory activities of lectin from marine red alga Pterocladiella capillacea. Biol. Pharm. Bull. 2010, 33, 830-835.

7. Calvete, J. J.; Costa, F. H. F.; SakerSampaio, S.; Murciano, M. P. M.; Nagano, C. S.; Cavada, B. S.; Grangeiro, T. B.; Ramos, M. V.; Bloch Jr, C.; Silveira, S. B.; others The amino acid sequence of the agglutinin isolated from the red marine alga Bryothamnion triquetrum defines a novel lectin structure. Cell. Mol. Life Sci. 2000, 57, 343.

8. Molchanova, V.; Chernikov, O.; Chikalovets, I.; Lukyanov, P. Purification and partial characterization of the lectin from the marine red alga Tichocarpus crinitus (Gmelin) Rupr.(Rhodophyta). Bot. Mar. 2010, 53, 69-78.

9. Nagano, C. S.; Debray, H.; Nascimento, K. S.; Pinto, V.; Cavada, B. S.; SakerSampaio, S.; Farias, W. R.; Sampaio, A. H.; Calvete, J. J. HCA and HML isolated from the red marine algae Hypnea cervicornis and Hypnea musciformis 
define a novel lectin family. Protein Sci. 2005, 14, 2167-2176.

10. Shim, E.; Shim, J.; Klochkova, T. A.; Han, J. W.; Kim, G. H. Purification of a sexspecific lectin involved in gamete binding of aglaothamnion callophyllidicola (rhodophyta). J. Phycol. 2012, 48, 916-924.

11. Suttisrisung, S.; Senapin, S.; Withyachumnarnkul, B.; Wongprasert, $\mathrm{K}$. Identification and characterization of a novel legume-like lectin cDNA sequence from the red marine algae Gracilaria fisheri. J. Biosci. 2011, 36, 833843.

12. Gonzaga do Nascimento-Neto, L.; Carneiro, R. F.; Da Silva, S. R.; Da Silva, B. R.; Arruda, F. V. S.; Carneiro, V. A.; do Nascimento, K. S.; Saker-Sampaio, S.; da Silva, V. A.; Porto, A. L. F.; others Characterization of isoforms of the lectin isolated from the red algae Bryothamnion seaforthii and its prohealing effect. Mar. Drugs 2012, 10, 1936 1954.

13. Nascimento, K. S.; Nagano, C. S.; Nunes, E. V.; Rodrigues, R. F.; Goersch, G. V.; Cavada, B. S.; Calvete, J. J.; SakerSampaio, S.; Farias, W. R.; Sampaio, A. $\mathrm{H}$. Isolation and characterization of a new agglutinin from the red marine alga Hypnea cervicornis J. Agardh. Biochem. Cell Biol. 2006, 84, 49-54.

14. Medina-Ramirez, G.; Gibbs, R. V.; Calvete, J. J.; Carpenter, B. G. Microheterogeneity and molecular assembly of the haemagglutinins from the red algae Bryothamnion seaforthii and B. triquetrum from the Caribbean Sea. Eur. J. Phycol. 2007, 42, 105-112.

15. Hori, K.; Nang, H. Q.; Kha, T.; others Seasonal changes in growth rate, carrageenan yield and lectin content in the red alga Kappaphycus alvarezii cultivated in Camranh Bay, Vietnam. J. Appl. Phycol. 2009, 21, 265-272.

16. Ly, B. M.; Trang, V. T. D.; Ngoc, N. T. D.; Trinh, P. T. H.; others A new screening for hemagglutinins from Vietnamese marine macroalgae. J. Appl. Phycol. 2012, $24,227-235$.
17. Atmadja, W. S.; Kadi, A.; Sulistijo, R. Pengenalan jenis-jenis rumput laut Indonesia; Puslitbang Oseanologi. LIPI.: Jakarta, 1996;

18. Hori, K.; Miyazawa, K.; Ito, K. Preliminary Characterization of Agglutinins from Seven Marine Algal Species. Nippon Suisan Gakkaishi 1986, 52, 323-331, doi:10.2331/suisan.52.323.

19. Takahashi, Y.; Katagiri, S. Seasonal Variation of the Hemagglutinating Activities in the Red Alga Gracilaria verrucosa. Nippon Suisan Gakkaishi 1987, 53 , 2133-2137, doi:10.2331/suisan.53.2133. 